\title{
Diurnal Blood and Urine Glucose and Acetone Bodies in Labile Juvenile Diabetics on One - and Two-Injection Insulin Therapy*
}

\author{
Hans K. Åkerblom and Hilkka Hiekrkala
}

The Children's Hospital, University of Helsinki, Helsinki, Finland

Received: February 20, 1969

\begin{abstract}
Summary. Diurnal levels of blood and urine glucose and acetone bodies were studied in 13 labile juvenile diabetics to see whether the control of diabetes could be improved by giving insulin twice instead of once daily. Lente insulin was used in most patients for one-injection therapy, and the biphasic Rapitard insulin (Novo) for two-injection therapy. Blood specimens were obtained six times daily, and urine was collected in four six-hour periods. Each patient was his own control. The patients presented hyperglycaemia, excessive glucosuria, hyperketonaemia and ketonuria on one-injection therapy, most remarkably in the morning. When the patients were given insulin twice a day and the total daily dose of insulin was unchanged, even if the control of diabetes was not good, hyperglycaemia and hyperketonaemia in the morn. ing were significantly lower than during one-injection therapy, and diurnal glucosuria and ketonuria decreased also.
\end{abstract}

Le glucose ainsi que les corps cétoniques dans le sang et l'urine chez le diabétique jeune recevant une ou deux in. jections d'insuline par jour.

Résumé. Les variations diurnes du glucose dans le sang et l'urine, ainsi que celles des corps cétoniques furent étudiées chez 13 diabétiques jeunes. Cette étude avait pour but de déterminer si l'équilibre du diabète pouvait être amélioré en donnant de l'insuline deux fois par jour au lieu d'une. De l'insuline lente fut donnée aux patients recevant une seule irjoction et, de l'insuline biphasique Rapitard (Novo) dans le cas des deux injections. Six échantillons de sang furent pris quotidiennement et, l'urine fut collectée en quatre périodes de six heures. Chaque patient était son propre témoin. Hyperglycémie, intense glucosurie, hypercétonémie et cétonurie étaient présentes, surtout le matin, chez les patients recevant une seule injection. Toutefois, quand cette même dose d'insuline fut administrée en deux injections séparées, même si l'équilibre du diabète n'était pas bon l'hyperglycémie et l'hypercétonémie étaient significativement plus basses que dans le cas d'une seule injection. Il en était de naême pour la glucosurie et la cétonurie.

Blutzucker- und Blutacetonkörpertagesproflle, sowie die Tagesschwankungen der Glucosurie und Acetonurie bei labilem jugendlichen Diabetes mellitus unter Behandlung mit ein oder zwei Insulininjektionen pro Tag

Zusammenfassung. Die Tagesschwankungen von Blutzucker, Blutacetonkörpern, Glucosurie und Acetonurie wurden bei 13 labilen jugendlichen Diabetikern unter. sucht, um zu klären, ob die Kontrolle des Diabetes mit zwei statt einer täglichen Insulininjektion besser gelang. Für die Behandlung mit einer Insulingabe/Tag wurde in den meisten Fällen Lente-Insulin, für die Therapie mit 2 täglichen Injektionen Rapitard Insulin (Novo) verwandt. Blutproben wurden $6 \times$ täglich entnommen, und der Harn in Perioden von 4-6 Std gesammelt. Jeder Patient diente als seine eigene Kontrolle. Die Patienten wiesen eine Hyperglykämie, eine ausgeprägte Glucosurie, Hyperketonämie und eine Acetonurie auf, die sich beson. ders morgens bemerkbar machte, wenn Insulin nur einmal am Tag gespritzt wurde. Erhielten die Patienten bei unveränderter Tagesdosis das Insulin auf 2 Injektionen verteilt verabreicht, so fielen die Morgenhyperglykämie und die morgendliche Hyperketonämie signifikant niedriger aus als unter einer Injektion/Tag. Die Glucosurie und die Acetonurie gingen auch dann zuríck, wenn sich keine befriedigende Einstellung erzielen ließ.

Key-words: Diurnal blood glucose, blood acetone bodies, glucosuria, ketonuria, labile juvenile diabetes, oneinjection, two-injection insulin therapy.
Labile juvenile diabetes brings about many therapeutic problems. For the insulin therapy, it is essential to find out the best possible individual dose, type of insulin and frequency of administration. A common problem is to assess whether a labile juvenile diabetic can be treated and controlled at all satisfactorily by intermediate-acting insulin, given once a day.

The difficulties in the evaluation of the control of diabetes are well-known. Blood glucose levels and glucosuria probably do not provide enough information of the control, for it is known that blood glucose levels may be quite normal, yet nevertheless there may

* A part of this work was presented at the Third Meeting of the Scandinavian Society for the Study of Diabetes, Oslo, February 3, 1967. be signs of derangement of the intermediary metabolism, for instance in the form of hyperketonaemia (Werk and Knowles, 1961). Therefore, a simultaneous measurement of both blood glucose and acetone bodies, and of glucosuria and ketonuria should permit a better assessment of the control of diabetes and of the efficacy of the treatment. Krainick and Müller (1938) already recommended the use of the "day profile" of blood acetone bodies as a contributory index of the control of diabetes. Davidson and Kaye (1965), who unexpectedly found elevated levels of blood acetone bodies in some of their apparently well-controlled diabetic patients, also pointed out the value of the determination of diurnal blood acetone bodies in assessing diabetic children. Some authors (Molnar et al., 1965) advocated fractional quantitative measurement of glucose and 
acetone bodies in urine in the study and clinical management of labile diabetics.

The present report describes the diurnal levels of blood glucose and acetone bodies, as well as of glucosuria and ketonuria in a group of labile juvenile diabetics. The purpose of the study was to see whether the control of diabetes could be improved by giving insulin twice instead of once a day. sampling took place on the average three to four days after the change in the frequency of insulin administration. In "Results" we call, for the sake of brevity, the day when insulin was given once "day I", and the day with two insulin injections "day II'. Lente insulin was given to all but one patient on "day I", and Rapitard 1 insulin to all except one diabetic on "day II". Insulin Rapitard is a mixture of dissolved quick-acting insulin

Table 1. Clinical data on 13 labile juvenile diabetics, studied for diurnal levels of blood glucose and acetone bodies, glucosuria and ketonuria when insulin was given once and twice daily

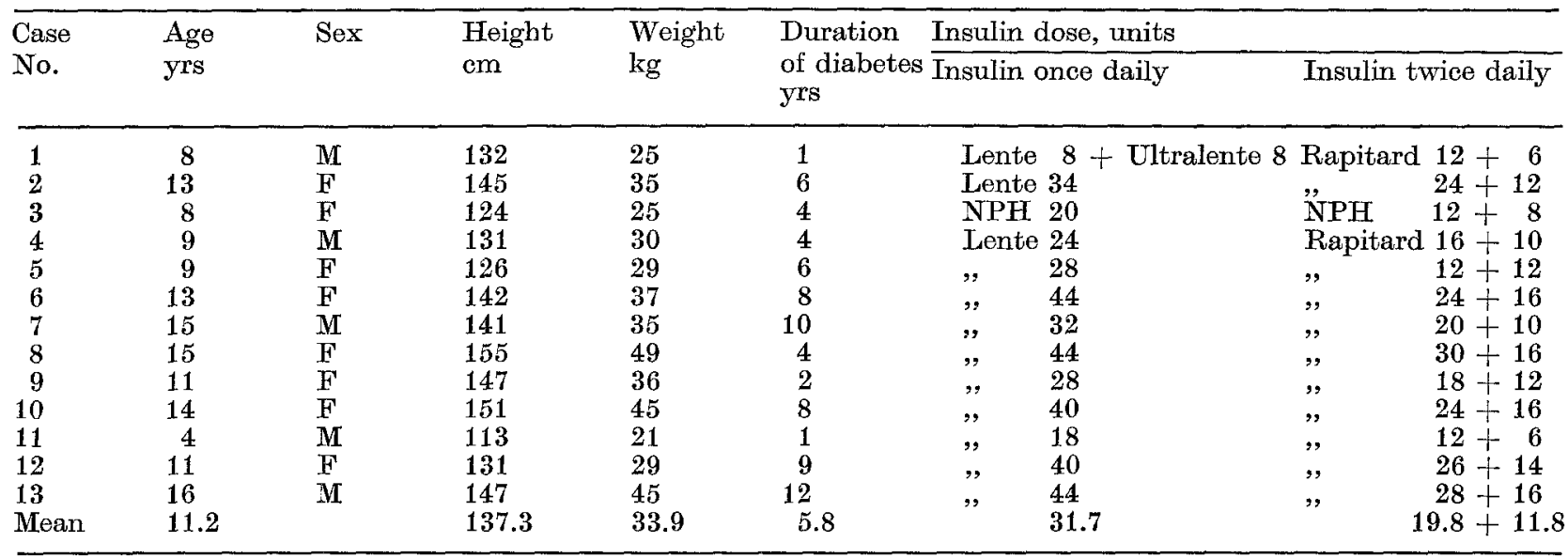

\section{Patients and methods}

In recent years we have employed the determination of diurnal levels of blood glucose and acetone bodies as a routine in the evaluation of the control in labile diabetic children, admitted to the hospital because of poor control. We included in the present study those labile diabetics who fulfilled the following criteria: 1. Insulin therapy was changed from one to two or from two to one daily injections during the hospital stay. 2. Diurnal blood glucose and acetone bodies, glucosuria and ketonuria were studied during both types of insulin treatment. 3 . The individual total daily dose of insulin was the same during one- and twoinjection therapy, or varied by at most four units. Thirteen patients formed the study group. The diurnal specimens were obtained between March 1965 and March 1967. Pertinent clinical data are given in Table 1.

The reasons for the poor control of diabetes at admission were previous infections, dietary errors and in some cases unexplained lability. Several diabetics had repeatedly had hypoglycaemic reactions at home. None of the patients had albuminuria. Three diabetics had been acidotic at admission (cases 2, 8, 12). The first diurnal sampling took place five to seven days after the disappearance of the signs of acidosis. Nine diabetics were studied first when receiving insulin once a day; and in the other four patients, who had been on two-injection therapy prior to admission the first diurnal specimens were taken when insulin was given twice daily (cases $8,9,10,13$ ). The second diurnal
$(25 \%)$ and suspended insulin crystals of intermediate action $(75 \%)$ and the preparation has a biphasic action (Schlichtkrull et al., 1965). NPH-insulin was given to one patient both once and twice a day. The evening insulin dose on "day II" was on the average $37 \%$ of the total daily dose. The morning insulin was given at 7.15 a.m. On "day II" the second dose of insulin was given at 7.15 p.m. The mealtimes were as follows: 8 a.m., 11.30 a.m., 2 p.m., 5 p.m., and 8 p.m. The diet contained a moderate amount of carbohydrate, and it was poor in fat and rich in protein. The daily amount of calories was calculated in the following way: 1000 calories + (age in years $\times 100)$. Therefore, the mean consumption was around 2000 calories/day. On "day II" dinner was smaller and evening snack bigger than on "day I".

Capillary blood was drawn at 7 a.m., 9 a.m., at noon, 3 p.m., 7 p.m., 10 p.m. and the next morning at 7 a.m. The fasting 7 a.m. specimen at the start of the diurnal sampling was taken from only seven patients. Blood glucose was determined by the o-toluidine method (Hyvärinen and Nikkilä, 1962). Specimens for the determination of acetone bodies were taken into heparinized tubes and kept frozen until analysis. Urine was collected during four six-hour periods $8 \mathrm{a} . \mathrm{m}$. -2 p.m., $2-8$ p.m., 8 p.m. -2 a.m., and $2-8$ a.m., and the urines were kept in the cold. Glucosuria was measured by polarimetry, and aliquots of the urine samples were stored frozen until the determina-

\footnotetext{
1 Novo Laboratories, Copenhagen.
} 
tion of acetone bodies was performed. Ketonuria was studied in ten patients. Blood and urine acetone bodies were measured by the microdistillation procedure of Ahola and Somersalo (1963), in which furfural is used as a colour-trapping agent. The amount of total acetone bodies, i. e. the sum of acetoacetate, $\beta$-hydroxybutyrate and acetone, is expressed for blood in $\mathrm{mmole} / \mathrm{l}$, and for urine in mmole/day. All determinations were done in duplicate. The significance of differences between mean values was calculated by Student's $t$-test, and between paired values according to Dunn (1964). When the distribution of values for acetone bodies was skew, logarithmic values were employed in the calculations of significance.

\section{Results}

Blood glucose ( $B G$ ). The mean diurnal BG values, $\mathrm{mg} / 100 \mathrm{ml} \pm \mathrm{SE}$ are presented in Fig. 1. Excessive hyperglycaemia occurred on both "day I" and "day II". On the former day, very high BG values were recorded in the morning both in fasting specimens and after breakfast, and also in the last evening-specimen (at 10 p.m.); whereas on "day II" the peak was at 7 p.m. in the postcibal specimen. BG was below $80 \mathrm{mg} / 100 \mathrm{ml}$ on "day $\mathrm{I}$ " in two cases in the morning at the start of sampling, in two other patients at 3 p.m., and on "day II" in one patient at 7 a.m. at the end of the diurnal sampling. None of these diabetics were clinically hypoglycaemic.

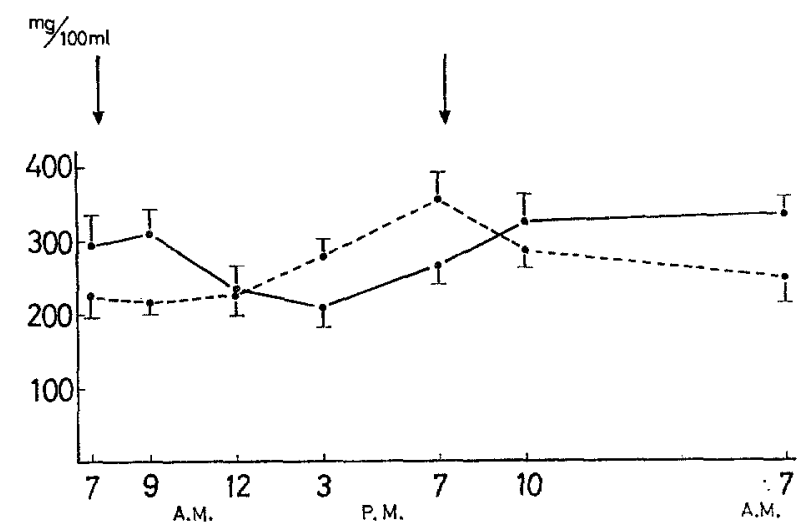

Fig. 1. Diurnal blood glucose values, $\mathrm{mg} / 100 \mathrm{ml}$ (mean and SE) in labile juvenile diabeties on one- and twoinjection therapy. Insulin once daily. ......... Insulin twice daily. The arrows denote the time of insulin injection(s)

The following significant differences were found between the mean BG values of the two diurnal curves: On "day I" BG was higher than on "day II" at 9 a.m. $(P<0.02)$ and at 7 a.m. at the end of the diurnal sampling $(P<0.05)$. When a paired comparison was done for each patient, the mean differences in BG between "day I" and "day II" were significant at the $5 \%$ level at 9 a.m. and at 7 a.m. at the end of the curve; thus confirming the finding of higher morning hyperglycaemia on "day I" than on "day II". The paired comparison showed on the other hand, that the 3 p.m. BG value was significantly higher on "day II" than on "day I" $(P<0.02)$.

Glucosuria. The mean glucosuria/six hours in $\mathrm{g} \pm \mathrm{SE}$ is shown in Fig. 2. The patients excreted large amounts of glucose both on "day I" and "day II". On the former day, the average 24 -h excretion soared to $105.2 \mathrm{~g}$, and on "day II" the mean diurnal glucosuria was $69.8 \mathrm{~g}$. In a paired comparison of $24-\mathrm{h}$ glucosuria for each patient, the mean differences between "day I" and "day II" were significant at the $5 \%$ level. The six-hour urines, collected between $8 \mathrm{a} . \mathrm{m}$. and $2 \mathrm{p.m}$. and from 2 to 8 a.m. contained significantly more glucose on "day I" than on "day II" $(P<0.02$ in both instances). The shape of the histogram depicting the mean glucosuria per six hours (Fig. 2) corresponds fairly well to the respective diurnal BG curve (Fig. 1).

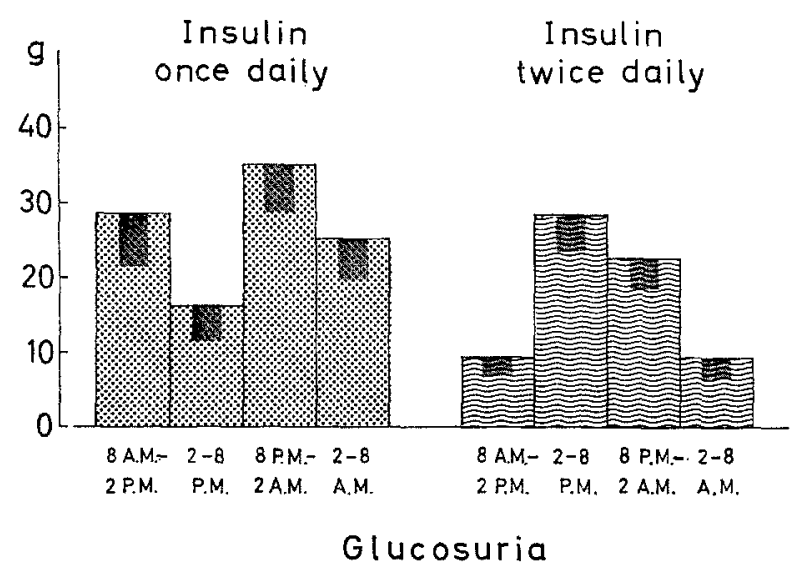

Fig. 2. Glucosuria, g/six hours (mean and SE) in 13 labile juvenile diabetics receiving insulin once and twice daily

Blood acetone bodies ( $B A c B o$ ). The mean diurnal concentrations of total $\mathrm{BAcBo}, \mathrm{mmole} / \mathrm{S} \pm \mathrm{SE}$, are shown in Fig. 3. Normal fasting values for total BAcBo, determined by the method used in the present study, have been found to range from 0.01 to $0.54 \mathrm{mmole} / \mathrm{l}$ in healthy 6 to 15 years old children (Åkerblom et al., 1965). We considered in the present work the total $\mathrm{BAcBo}$ values to indicate hyperketonaemia if they exceeded $0.4 \mathrm{mmole} / \mathrm{l}$. - The mean diurnal curves show morning hyperketonaemia on both "day I" and "day II", but on the former day the hyperketonaemia was considerably higher than on the latter. The mean total BAcBo values (logarithmic) were significantly higher on "day I" than on "day II" at 9 a.m. $(P<$ $0.02)$, and at $7 \mathrm{a} . \mathrm{m}$. at the end of the diurnal sampling $(P<0.02)$. When the results on each patient from the two diurnal curves were paired, the mean differences in total BAcBo between "day I" and "day II" were significant at the $2 \%$ level at 9 a.m., and at 7 a.m. at the end of the diurnal curve. 
Correlation of $B G$ to $B A c B o$. Significant correlations were found between BG and total BAcBo on "day I" as follows: At noon $(r+0.69, P<0.02)$, at $10 \mathrm{p} . \mathrm{m}$. $(r+0.79, P<0.005)$ and 7 a.m. $(r+0.95, P<$ 0.001). On "day II" a significant correlation between $\mathrm{BG}$ and $\mathrm{BAcBo}$ was present only at $7 \mathrm{a} . \mathrm{m}$. at the end of the diurnal sampling $(r+0.77, P<0.005)$.

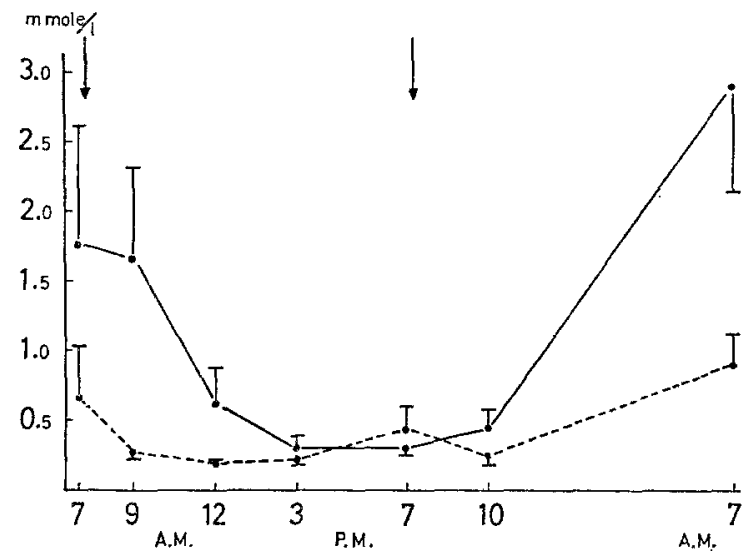

Fig. 3. Diurnal values for total blood acetone bodies, mmole/1 (mean and SE) in labilo juvenile diabetics on one-and two-injection therapy. ___ Insulin once daily. ......... Insulin twice daily. The arrows denote the time of insulin injection(s)

Ketonuria. The mean excretion of total acetone bodies in urine, expressed in mmole/day is given in Table 2. The average 24-hour ketonuria of the ten patients studied was more than sevenfold on "day I" compared with that of "day II", the mean logarithmic values being significantly different $(P<0.02)$. The

Table 2. Excretion of total acetone bodies in urine, mmotel six hours and $24 h$ (mean $\pm S E$ ) in ten labile juvenile diabetics receiving insulin once and twice daily

\begin{tabular}{|c|c|c|}
\hline & $\begin{array}{l}\text { Insulin once } \\
\text { daily }\end{array}$ & $\begin{array}{l}\text { Insulin twice } \\
\text { daily }\end{array}$ \\
\hline & $\begin{array}{l}\text { Total acetone } \\
\text { bodies, mmole }\end{array}$ & $\begin{array}{l}\text { Total acetone } \\
\text { bodies, mmole }\end{array}$ \\
\hline $\begin{array}{l}8 \text { a.m. }-2 \text { p.m. } \\
2-8 \text { p.m. } \\
8 \text { p.m. }-2 \text { a.m. } \\
2-8 \text { a.m. } \\
\text { Per } 24 \text { h }\end{array}$ & $\begin{array}{l}5.8 \pm 3.6 \\
0.23 \pm 0.06 \\
0.28 \pm 0.09 \\
1.7 \pm 1.0 \\
8.0 \pm 3.6\end{array}$ & $\begin{array}{l}0.22 \pm 0.05 \\
0.33 \pm 0.06 \\
0.36 \pm 0.11 \\
0.18 \pm 0.03 \\
1.10 \pm 0.20\end{array}$ \\
\hline
\end{tabular}

mean difference between "day I" and "day II" 24-h ketonuria in a paired comparison on each of the ten patients was significant $(P<0.01)$. The major part of the increased quantities of acetone bodies was excreted on "day I" during the night and early morning. No significant correlation was found on either day between 24-h glucosuria and diurnal ketonuria $(r+0.06$ on "day I" and +0.26 on "day II").

\section{Discussion}

We have compared directly the diurnal results obtained during the insulin therapy regimens for the following reasons: the individual daily dose of insulin was the same or very close to it for both types of treatment (Table 1); and we have assumed that, other than insulin, the factors affecting the control of diabetes influenced each patient in the same way during one- and two-injection therapy. We shall discuss the matter of the sequence of the two regimens later on.

Our patients showed a marked diabetic instability when intermediate-acting insulin was given once a day. The mean $\mathrm{BG}$ and $\mathrm{BAcBo}$ values indicated that the metabolic derangements were especially large in the morning. However, the mean BG had already risen to a very high level at 10 p.m., and the lowest $B G$ value was $139 \mathrm{mg} / 100 \mathrm{ml}$ at this hour. This, together with the occurrence of the mean peak glucosuria/six hours between 8 p.m. and 2 a.m., might indicate that many patients were hyperglycaemic during the night, although $\mathrm{BG}$ was not measured between 10 p.m. and 7 a.m. In unstable diabetics, the two most common causes of morning hyperketonaemia and ketonuria are insufficient effect of insulin during the night and early morning, and on the contrary hypoglycaemia (Somogyi, 1941). As regards our study, in addition to what was mentioned before about evening and night hyperglycaemia, the $2-8 \mathrm{a} . \mathrm{m}$. urine of all patients contained glucose. Therefore, in our series relative lack of insulin during the night seemed to explain better the morning hyperketonaemia and ketonuria. But some diabetics may have hypoglycaemic reactions despite hyperglycaemia, if a rapid fall of $\mathrm{BG}$ occurs (Bolinger et al., 1964). Such a phenomenon might have come about in some of our patients during the night, and contributed to the morning hyperketonaemia. In addition, several patients had in their history hypoglycaemic reactions.

When insulin was given twice a day the control of diabetes was not good either. But the significantly lower hyperglycaemia and hyperketonaemia in the morning, and the significantly smaller diurnal glucosuria and ketonuria in the paired comparison showed that the patients' diabetes was better controlled by two-injection than by one-injection therapy. The mean peak $B G$ value was recorded at $7 \mathrm{p} . \mathrm{m}$. in a postprandial sample, before the administration of the second insulin dose. The postprandial evening hyperglycaemia during two-injection therapy might be reduced by giving the second insulin dose earlier than what happened in our study. - The four patients who were studied at first on two-injection therapy and later on one daily insulin dose, had, in general, lower morning hyperglyeaemia and hyperketonaemia and less glucosuria when they received insulin twice daily than once a day. Accordingly it seemed unlikely that the sequence of the two therapeutic regimens would have influenced the results of the comparisons. 
The biphasic Rapitard insulin, which was given to all except one of our patients during two-injection therapy, has been shown by Schlichtkrull and coworkers (1965) to give a better control than other insulins of the hyperglycaemic peak after breakfast and also throughout the day, both in one- and two-injection therapy. Schlichtkrull et al. used the M-formula for their evaluation. Kappeler (1966) recommended Rapitard in particular for unstable diabeties presenting nocturnal hypoglycaemia and morning hyperglycaemia, and he observed that the quantity of Rapitard required per day for two-injection therapy was $20 \%$ higher compared with the dose of Lente insulin. Our experience as well, is that most juvenile diabetics who are changed from one-injection therapy to Rapitard twice a day do best when their daily dose of Rapitard insulin is somewhat higher than the previous dose of intermediate-acting insulin given once a day.

In a study of fasting levels and diurnal variation in blood lipids and acetone bodies in juvenile diabetios, Sterky et al. (1966) found the fasting values for FFA and acetone bodies to be elevated in patients on oneinjection therapy, whereas those taking insulin twice a day had normal FFA level, lower acetone bodies in blood and less diurnal variation in blood sugar. The diurnal curves for total BAcBo in our study (Fig. 3) are of the same shape as the curves given in the paper of Sterky and co-workers. These authors concluded that juvenile diabetics ought to be given insulin twice daily, in view of the possibility of prognostically unfavourable effects of elevated blood acetone bodies or FFA.

Our results similarly show the advantage of giving insulin twice a day to juvenile diabetics. Two-injection therapy proved to be beneficial in labile patients by curtailing morning hyperglycaemia and diurnal glucosuria. In particular, two-injection therapy turned out to be effective in the reduction of hyperketonaemia and ketonuria, which are certainly harmful in the short term and probably also in the long run. Our results clearly speak in favour of two-injection therapy in at least the labile juvenile diabetics.

Acknowledgements: This study was supported by the Foundation for Pediatric Research in Finland. The ex- pert technical help rendered by Tom Ahola, M.Sc., and the skilful technical assistance of Miss Eva Forssell are gratefully acknowledged.

\section{References}

Ahola, T., Somersalo, O.: Microdetermination of acetone bodies in blood and urine. Ann. Med. exp. Fenn. 41, $237-246$ (1963).

Åkerblom, H., Ahola, T., Somersalo, O. $(\dagger)$ : Acetone bodies in blood of infants and children of various ages. Ann. Paediat. Fenn. 11, 108-113 (1965).

Bolinger, R.E., Stephens, R., Lukert, B., Diederich, D.: Galvanic skin reflex and plasma free fatty acids during insulin reactions. Diabetes $13,600-605$ (1964).

Davidson, M.H., Kaye, R.: A study of blood glucose and ketone bodies and plasma free fatty acids, cholesterol, phospholipids and total lipids in juvenile diabetes. J. Pediat. 66, 313-321 (1965).

Dunn, O.J.: Basic Statistics: A Primer for the Biomedical Sciences, p. 90. New York: John Wiley \& Sons, Inc. 1964.

Hyvärinen, A., Nikkilä, E.A.: Specific determination of blood glucose with o-toluidine. Clin. chim. Acta 7, $140-143(1962)$.

Kappeler, H.J.: Einstellung labiler Diabetiker mit Insulin Rapitard. Schweiz. med. Wschr. 96, 1450-1456 (1966).

Krainick, H.G., Müller, F.: Zur Physiologie und Pathologie des intermediëren Fettstoffwechsels. VI. Mitteilung. Das diabetische Blutketontagesprofil. Klin. Wschr. 17, 1760-1762 (1938).

Molnar, G.D., Gastineau, C.F., Rosevear, J.W., Moxness, K.E.: Quantitative aspects of labile diabetes. Diabetes 14, 279-288 (1965).

Schlichtkrull, J., Munck, O., Jersild, M.: Insulin Rapitard. and Insulin Actrapid. Acta med. scand. 177, 103-113 (1965).

Somogyi, M.: Effects of insulin upon the production of ketone bodies. J. biol. Chem. 141, 219-227 (1941).

Sterky, G.C.G., Persson, B.E.H., Larsson, Y.A.A.: Dietary fats, the diurnal blood lipids and ketones in juvenile diabetes. Diabetologia 2, 14-19 (1966).

Werk, E.E., Jr., Knowles, H.C., Jr.: The blood ketone and plasma free fatty acid concentration in diabetic and normal subjects. Diabetes 10, 22-32 (1961).

Dr. Hans K. Akerblom

The Children's Hospital University of Helsinki

11 Stenbäck Street

Helsinki 29, Finland 